\title{
NITROGEN AND ORGANIC FERTILIZATION ON GRAPEVINE PRODUCTIVITY IN THE BRAZILIAN SEMIARID REGION ${ }^{1}$
}

\author{
FRANCIEZER VICENTE DE LIMA ${ }^{2 *}$, VANDER MENDONÇA ${ }^{3}$, FRANCISCO SIDENE OLIVEIRA SILVA $^{3}$, \\ FRANCISCO MICKAEL DE MEDEIROS CÂMARA ${ }^{3}$, TONI HALAN DA SILVA IRINEU ${ }^{3}$
}

\begin{abstract}
Nitrogen fertilization is a limiting factor for grapevine production; its excess or deficiency can cause changes in fruit quantity and quality. Thus, the objective of this work was to evaluate productive parameters of grapevines of the Isabel-Precoce cultivar subjected to nitrogen and organic fertilization in the western semiarid region of the state of Rio Grande do Norte (RN), Brazil. The experiment was conducted at the Experimental Farm of the Federal Rural University of the Semi-Arid Region, in Mossoró, RN, Brazil, during two production cycles. The soil of the area used was classified as dystrophic Red Argissolo (Udult) of sandy texture. The experiment was conducted in a randomized block design with six replications, using a $5 \times 2$ factorial arrangement, with 5 nitrogen fertilizer rates $\left(0,30,60,90\right.$, and $\left.120 \mathrm{~kg} \mathrm{ha}^{-1}\right)$ and two organic fertilizer rates $\left(0\right.$, and $20 \mathrm{~m}^{3} \mathrm{ha}^{-1}$ of bovine manure). The production components number of bunches per plant, grape production per plant, grape yield, weight, length and width of bunches, number of berries per bunch, and tenberry weight were evaluated. The nitrogen rates and organic fertilizer rates used were significant $(p \leq 0.05)$ for all evaluated components. The $\mathrm{N}$ rate of $60 \mathrm{~kg} \mathrm{ha}^{-1}$ combined with the organic fertilization generated the best results for the analyzed variables. $\mathrm{N}$ rates from 60 to $120 \mathrm{~kg} \mathrm{ha}^{-1}$, applied singly or combined with organic fertilizer, hindered the production components of the Isabel-Precoce grapevines.
\end{abstract}

Keywords: Vitis labrusca L. Bovine manure. Mineral fertilizer. Isabel-Precoce.

\section{COMPONENTES DE PRODUÇÃO DA VIDEIRA 'ISABEL PRECOCE’ SUBMETIDA À ADUBAÇÃO NITROGENADA E ORGÂNICA NO SEMIÁRIDO POTIGUAR}

\begin{abstract}
RESUMO - A adubação nitrogenada na videira apresenta-se como um fator limitante na produção, visto que seu excesso ou deficiência são capazes de propiciar alterações na quantidade e qualidade final dos frutos. Assim, o objetivo deste trabalho foi avaliar os parâmetros produtivos da videira 'Isabel Precoce' submetida a adubação nitrogenada e orgânica na região semiárida do Oeste Potiguar. O experimento foi implantado na Fazenda Experimental da UFERSA, em Mossoró, RN, cujo clima é semiárido. O solo da área é um Argissolo Vermelho Distrófico de textura arenosa. A pesquisa foi realizada em dois ciclos de produção. O delineamento experimental utilizado foi blocos casualizados com seis repetições, em esquema fatorial $5 \times 2$, que corresponderam a 5 doses de fertilizante nitrogenado $\left(0,30,60,90\right.$ e $\left.120 \mathrm{~kg} \mathrm{ha}^{-1}\right)$, na ausência e presença de adubação orgânica ( 0 e $20 \mathrm{~m}^{3} \mathrm{ha}^{-1}$ esterco bovino). Foram avaliados número de cachos por planta, produção por planta e produtividade, bem como peso, comprimento e largura dos cachos, número de bagas por cacho e peso de dez bagas. A aplicação das doses de nitrogênio $(\mathrm{N})$, bem como o uso ou não de adubo orgânico (AO) no solo, conferiram efeito significativo $(\mathrm{p} \leq 0,05)$ para todos os componentes avaliados. A dose de $60 \mathrm{~kg} \mathrm{ha} \mathrm{g}^{-1} \mathrm{de} \mathrm{N}$ na presença do AO foi a que proporcionou os melhores resultados nas variáveis analisadas. A elevação dos níveis de $\mathrm{N}$, a partir da dose de 60 até $120 \mathrm{~kg} \mathrm{ha}^{-1}$ combinadas ou não a fonte orgânica, inibiram os componentes produtivos da videira 'Isabel Precoce'.
\end{abstract}

Palavras-chave: Vitis labrusca L. Esterco bovino. Fertilizante mineral. Produtividade.

\footnotetext{
*Corresponding author

${ }^{1}$ Received for publication in $11 / 27 / 2017$; accepted in $09 / 11 / 2018$.

Paper extracted from the doctoral thesis of the first author.

${ }^{2}$ Post-Graduate Program in Soil and Water Management, Universidade Federal Rural do Semi-Árido, Mossoró, RN, Brazil; franciezer@hotmail.com - ORCID: 0000-0003-1289-143X.

${ }^{3}$ Post-Graduate Program in Plant Production, Universidade Federal Rural do Semi-Árido, Mossoró, RN, Brazil; vander@ufersa.edu.br ORCID: 0000-0001-5682-5341,f_sidene@hotmail.com - ORCID: 0000-0001-8488-025X, mickaelmedeiros@hotmail.com - ORCID: 0000 -0003-2119-9592, tonnysilva@hotmail.com - ORCID: 0000-0003-4628-5833.
} 


\section{INTRODUCTION}

The irrigated production of tropical fruits in the West region of the state of Rio Grande do Norte, Brazil, mad this region one of the most dynamic regions of fruit production in the Brazilian Northeast region. High-technology producing areas reached 12,000 hectares in 2016; and melon exports generated, for example, a turnover of US\$ 75.3 million (CARVALHO et al., 2017). Several other native and exotic fruit species produced in other Brazilian northeastern states have potential in this region, since these states have similar climatic characteristics, well-established production chain for tropical fruits, and possibility of production in the whole year due to their soil and climatic conditions.

Grapevine is one of these species; it has a well-established production in the São Francisco Valley, which is a region that presents very similar conditions to those found in the semiarid region of Rio Grande do Norte. However, few studies have been carried out on viticulture in the Brazilian semiarid region outside the Sub-mid São Francisco Valley, making it difficult to find detailed information about the benefits and difficulties of producing grapevines under the soil and climatic conditions of the semiarid region to expand this crop production area in the country.

Part of the soils of the Brazilian northeastern semiarid region presents low organic matter content and, consequently, low capacity of supplying nutrients, especially nitrogen $(\mathrm{N})$, making necessary the application of mineral fertilizers to reach good production levels (CUNHA, 2008; CUNHA et al., 2010). The use of $\mathrm{N}$ affects the vegetative growth of the grapevine, production and composition of the berries, and the final quality of the fruits (BRUNETTO et al., 2009). $\mathrm{N}$ deficiency reduces productivity, however, $\mathrm{N}$ excess decreases fruit quality by stimulating competition between vegetative and reproductive activity of the plant (LORENSINI et al., 2015).

Thus, the application of manure to improve fertilization is a good alternative to supply nutrients to plants, especially $\mathrm{N}, \mathrm{P}$, and $\mathrm{K}$, presenting good results when properly managed (CASTOLDI et al., 2011; FREITAS; ARAÚJO; SILVA, 2012; ECKHARDT et al., 2016). Even small contributions of $\mathrm{N}$ from organic fertilizers are important, since they reduce subsequent chemical fertilizations, which are costly. Therefore, the production efficiency can be increased, generating economic gains for farmers, who often have these organic materials in their properties (LOURENZI et al., 2016).

Searching for a balanced nutrition of plants by increase the soil nutrients to levels that allow the vegetative and productive development of the grapevine is important (LORENSINI et al., 2014). However, no information on the response of the grapevine to nitrogen fertilization is found for the study region. The nutritional status of the plants influences the production and composition of the fruits; thus, $\mathrm{N}$ fertilizer should be used at specific rates to avoid this negatively influence on production components and contents of other nutrients in the plant and in the soil (ROCHA, BASSOI; SILVA, 2015). In this context, the objective of this work was to evaluate productive parameters of grapevines of the Isabel-Precoce cultivar subjected to nitrogen and organic fertilization in the western semiarid region of the state of Rio Grande do Norte (RN), Brazil.

\section{MATERIAL AND METHODS}

The experiment was conducted at the Rafael Fernandes Experimental Farm of the Federal Rural Semiarid University (UFERSA), in Mossoró, western state of Rio Grande do Norte, Brazil $\left(5^{\circ}\right.$ 03'37' 'S, 37 $23^{\prime} 50^{\prime}$ ' $\mathrm{W}$, and altitude of $\left.78 \mathrm{~m}\right)$. The region presents a BSw'h', tropical semiarid hot climate, according to the Köppen classification; average annual rainfall of $695.8 \mathrm{~mm}$; average temperature of $27.4{ }^{\circ} \mathrm{C}$, with two well-defined dry (prolonged) and wet (short and uneven) seasons; and flat relief. The natural vegetation is hyperxerophilous Caatinga. Table 1 shows meteorological data collected during the experiments.

The soil of the experimental area was classified as typic dystrophic Red Argissolo (Udult) of sandy texture (RÊGO et al., 2016). Soil samples of the $0-20 \mathrm{~cm}$ layer were collected and their physical and chemical characteristics were evaluated before the implementation of the experiment (EMBRAPA, 2011 ; TEDESCO et al, 1995); the results are presented in Table 2. 
Table 1. Rainfall, average temperature, and relative air humidity during the experiment period.

\begin{tabular}{cccc}
\hline Month & $\begin{array}{c}\text { Precipitation } \\
(\mathrm{mm})\end{array}$ & $\begin{array}{c}\text { Average Temperature } \\
\left({ }^{\circ} \mathrm{C}\right)\end{array}$ & $\begin{array}{c}\text { Relative air humidity } \\
(\%)\end{array}$ \\
\hline September & 0.0 & 2015 & 57.0 \\
October & 0.0 & 28.0 & 56.8 \\
November & 0.0 & 28.2 & 59.6 \\
December & 8.0 & 28.8 & 58.7 \\
\hline April & & & 63.7 \\
May & 51.0 & 2016 & 61.5 \\
June & 8.0 & 28.7 & 59.8 \\
July & 29.0 & 28.2 & 52.8 \\
\hline
\end{tabular}

Source: Meteorological station of the experimental farm of UFERSA.

Table 2. Chemical and physical characteristics of the typic dystrophic Red Argissolo (Udult) of sandy texture $(0-20 \mathrm{~cm}$ layer) before the implementation of the experiment.

\begin{tabular}{|c|c|c|c|}
\hline Attribute & Value & Attribute & Value \\
\hline $\mathrm{pH}\left(\mathrm{H}_{2} \mathrm{O}\right)$ & 7.95 & Saturation by bases & 100 \\
\hline Electrical Conductivity $\left(\mu \mathrm{S} \mathrm{m}^{-1}\right)$ & 80.0 & Saturation by aluminum & 0 \\
\hline Organic matter $\left(\mathrm{g} \mathrm{kg}^{-1}\right)$ & 4.07 & Exchangeable sodium (\%) & 1 \\
\hline $\mathrm{N}$ total $\left(\mathrm{g} \mathrm{kg}^{-1}\right)$ & 0.77 & $\mathrm{Cu}\left(\mathrm{mg} \mathrm{dm}^{-3}\right)$ & 1.11 \\
\hline $\mathrm{P}\left(\mathrm{mg} \mathrm{dm}^{-3}\right)$ & 39 & $\mathrm{Fe}\left(\mathrm{mg} \mathrm{dm}^{-3}\right)$ & 12.57 \\
\hline $\mathrm{K}^{+}\left(\mathrm{mg} \mathrm{dm}^{-3}\right)$ & 117 & $\operatorname{Mn}\left(\operatorname{mg~dm}{ }^{-3}\right)$ & 29.75 \\
\hline $\mathrm{Na}^{+}\left(\mathrm{mg} \mathrm{dm}^{-3}\right)$ & 49 & $\mathrm{Zn}\left(\mathrm{mg} \mathrm{dm}{ }^{-3}\right)$ & 4.0 \\
\hline $\mathrm{Ca}^{2+}\left(\mathrm{cmol}_{\mathrm{c}} \mathrm{dm}^{-3}\right)$ & 4.17 & Sand $\left(\mathrm{g} \mathrm{kg}^{-1}\right)$ & 836 \\
\hline $\mathrm{Mg}^{2+}\left(\mathrm{cmol}_{\mathrm{c}} \mathrm{dm}^{-3}\right)$ & 1.05 & Silt $\left(\mathrm{g} \mathrm{kg}^{-1}\right)$ & 84 \\
\hline $\mathrm{Al}^{3+}\left(\mathrm{cmol}_{\mathrm{c}} \mathrm{dm}^{-3}\right)$ & 0.0 & Clay $\left(\mathrm{g} \mathrm{kg}^{-1}\right)$ & 80 \\
\hline$(\mathrm{H}+\mathrm{Al})\left(\mathrm{cmol}_{\mathrm{c}} \mathrm{dm}^{-3}\right)$ & 0.0 & Soil density $\left(\mathrm{kg} \mathrm{dm}^{-3}\right)$ & 1.54 \\
\hline Sum of bases $\left(\mathrm{cmol}_{\mathrm{c}} \mathrm{dm}^{-3}\right)$ & 5.73 & Particle density $\left(\mathrm{kg} \mathrm{dm}^{-3}\right)$ & 2.63 \\
\hline Effective CEC $\left(\mathrm{cmol}_{\mathrm{c}} \mathrm{dm}^{-3}\right)$ & 5.73 & Total porosity (\%) & 41.44 \\
\hline Soil CEC $\left(\mathrm{cmol}_{\mathrm{c}} \mathrm{dm}^{-3}\right)$ & 5.73 & & \\
\hline
\end{tabular}

The research was conducted during two grapevine production cycles, the first from September 22 to December 23, 2015 (92 days), and the second from April 14 to July 20, 2016 (97 days), from the pruning to harvest. The grapevines used were from the Isabel-Precoce cultivar, which was grafted on the IAC-766 cultivar. They had been planted in the area in 2010, with spacing of $3 \mathrm{~m}$ between rows and $2 \mathrm{~m}$ between plants (1667 plants $\mathrm{ha}^{-1}$ ), using a trellis system with three NorthSouth oriented wires, and the first harvest was carried out in 2013 , thus, they were in a good period to evaluate their productive potential.

The cultural practices for the crop development were similar in both cycles, consisting of pruning, eliminating tendrils, and conduction of 
branches on the trellis. Weeds up to approximately $70 \mathrm{~cm}$ around the plants were removed and mechanical weeding was performed between rows before the application of the treatments, keeping the area free from weeds during the experiment to avoid their interference in the nutrient availability.

A micro sprinkler irrigation system was used, with 1-hour irrigation every 24 hours. The irrigation depths were calculated based on the reference evapotranspiration (ETo), using data from the meteorological station installed in the experimental farm. The water depths were applied according to the crop coefficient for each phenological phase (BASSOI et al., 2007).

The experiment was conducted in a randomized block design with six replications, using a $5 \times 2$ factorial arrangement, with 5 nitrogen fertilizer rates $\left(0,30,60,90\right.$, and $120 \mathrm{~kg} \mathrm{ha}^{-1}$; urea) and two organic fertilizer rates $\left(0\right.$, and $20 \mathrm{~m}^{3} \mathrm{ha}^{-1}$ of bovine manure; $13.3 \mathrm{Mg} \mathrm{ha}^{-1}$, dry basis). The nitrogen fertilizer was applied one week before pruning $(50 \%)$, and in four weekly applications $(50 \%)$. The organic fertilizer was applied in a single application together with the first nitrogen application. A sample of the organic fertilizer was analyzed for chemical characteristics; the results are described in Table 3. The mineral and organic fertilizers were applied to the soil surface and, subsequently, the area was irrigated to reduce $\mathrm{N}$ losses by volatilization.

Table 3. Chemical characteristics of the bovine manure used in the experiment, and amount of nutrients applied per plant, and per hectare through the organic fertilizer $\left(20 \mathrm{~m}^{3} \mathrm{ha}^{-1} ; 13.3 \mathrm{Mg} \mathrm{ha}^{-1}\right)$ in each crop cycle.

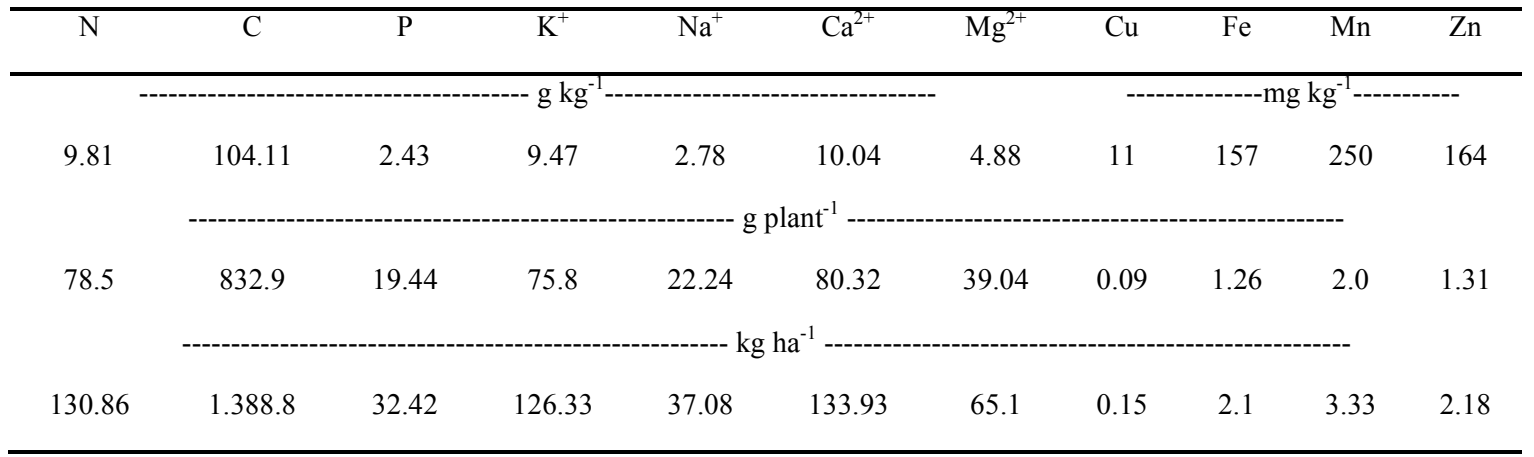

The soil analysis (Table 2) was used to evaluate the need for soil fertilization and provide optimum development conditions for the plants. The fertilization was carried out without $\mathrm{N}$, which was supplied by the treatments, following fertilization recommendations for grapevines (IPA, 2008), with $80 \mathrm{~kg} \mathrm{ha}^{-1}$ of $\mathrm{P}_{2} \mathrm{O}_{5}$ (simple superphosphate), and 150 $\mathrm{kg} \mathrm{ha}^{-1}$ of $\mathrm{K}_{2} \mathrm{O}$ (potassium chloride). Phosphorus was applied in a single application together with the first application of nitrogen, and potassium application followed the same scheduling used for the nitrogen rates.

Eight grape bunches were randomly collected from each plant at the end of each productive cycle, packed in plastic bags, placed in polyethylene boxes separated by treatment and replication, and taken to the Post-Harvest Laboratory of Physiology and Technology of the UFERSA for evaluation. Their weight, length, width, number of berries per bunch and ten-berry weight were evaluated. The grape production of each treatment was determined by multiplying the number of plants per hectare by the production of each plant in the treatments. The remaining bunches in the plants were harvested, quantified, and weighed to obtain the number of bunches per plant, and production per plant.

The results were subjected to analysis of variance, using the $\mathrm{t}$ test at $5 \%$ probability level to compare the means for the qualitative factor (organic fertilizer). The quantitative factor $(\mathrm{N})$ and interaction between the factors were analyzed through regression analysis, testing linear and quadratic models by the $\mathrm{F}$ test at $5 \%$ probability level, using the Expdes.pt. package of the $\mathrm{R}$ statistical program (R CORE TEAM, 2015).

\section{RESULTS AND DISCUSSION}

The nitrogen $(\mathrm{N})$ rates applied to the soil were significant $(p \leq 0.05)$ for all production components of the evaluated grapevines, regardless of the use of organic fertilizer (OrF). The variables presented increments with quadratic model in both cycles, regardless of the use of OrF. Thus, $\mathrm{N}$ rates above the requirements of the plants promote a negative effect, with no increase in grape production.

All $\mathrm{N}$ rates within the OrF rates increased bunch weight (BW), except the $0 \mathrm{~kg} \mathrm{ha}^{-1}$ of $\mathrm{N}$ (Table 4), although a better effect of OrF was expected. This was probably due to the immobilization of nutrients by the microbial biomass (MENEZES; SALCEDO, 2007). The high carbon content added to the soil through the $\operatorname{OrF}\left(1,389 \mathrm{~kg} \mathrm{ha}^{-1}\right.$, Table 3$)$ caused changes in the soil $\mathrm{C}$ to $\mathrm{N}$ ratio, favoring the 
immobilization process and, consequently, reduced nutrient availability to plants and BW. It also generated a longer time for the decomposition of the organic material and release of nutrients, possibly affecting the production components evaluated.

Table 4. Bunch weight (BW), number of berries per bunch (NBB), 10-berry weight (10BW), bunch length, and bunch width of grapevines of the Isabel-Precoce cultivar as a function of nitrogen fertilization, with and without the use of organic fertilizer, in two production cycles.

\begin{tabular}{|c|c|c|c|c|c|c|c|c|}
\hline \multirow{2}{*}{$\begin{array}{l}\text { Production } \\
\text { component }\end{array}$} & \multirow{2}{*}{ OrF } & \multicolumn{5}{|c|}{ Nitrogen rates $\left(\mathrm{kg} \mathrm{ha}^{-1}\right)$} & \multirow{2}{*}{ Equation } & \multirow{2}{*}{$\mathrm{R}^{2}$} \\
\hline & & 0 & 30 & 60 & 90 & 120 & & \\
\hline \multicolumn{9}{|c|}{$1^{\circ}$ Cycle } \\
\hline \multirow{2}{*}{ BW (g) } & Yes & $88.9 \mathrm{a}$ & $89.3 \mathrm{~b}$ & $89.3 \mathrm{~b}$ & $91.8 \mathrm{~b}$ & $78.2 \mathrm{~b}$ & $\mathrm{y}=86.873 * *+0.3469 \mathrm{x} * *-0.0034 \mathrm{x}^{2 * *}$ & $0.81 * *$ \\
\hline & No & $81.2 \mathrm{~b}$ & $99.9 \mathrm{a}$ & $104.8 \mathrm{a}$ & $96.4 \mathrm{a}$ & $82.4 \mathrm{a}$ & $\mathrm{y}=81.962 * *+0.7448 \mathrm{x} * *-0.0062 \mathrm{x}^{2 * *}$ & $0.98 * *$ \\
\hline \multirow{2}{*}{ NBB } & Yes & $31.0 \mathrm{a}$ & $32.8 \mathrm{~b}$ & $33.5 b$ & $32.2 \mathrm{a}$ & $27.4 \mathrm{a}$ & $\mathrm{y}=30.748 * *+0.1194 \mathrm{x} * *-0.0012 \mathrm{x}^{2 * *}$ & $0.97 * *$ \\
\hline & No & $28.1 \mathrm{~b}$ & $35.6 \mathrm{a}$ & $36.8 \mathrm{a}$ & $33.0 \mathrm{a}$ & $27.6 \mathrm{a}$ & $\mathrm{y}=28.516 * *+0.2832 \mathrm{x}^{* *}-0.0024 \mathrm{x}^{2 * *}$ & $0.96 * *$ \\
\hline \multirow{2}{*}{$10 \mathrm{BW}(\mathrm{g})$} & Yes & $30.2 \mathrm{a}$ & $31.2 b$ & $32.0 \mathrm{~b}$ & $32.7 \mathrm{~b}$ & $27.5 b$ & $\mathrm{y}=29.771 *+0.1053 \mathrm{x}^{*}-0.0009 \mathrm{x}^{2} *$ & $0.78^{*}$ \\
\hline & No & $28.4 \mathrm{~b}$ & $32.4 \mathrm{a}$ & $33.8 \mathrm{a}$ & $34.2 \mathrm{a}$ & $29.4 \mathrm{a}$ & $\mathrm{y}=28.205^{* *+0}+1907 \mathrm{x}^{* *}-0.0015 \mathrm{x}^{2 * *}$ & $0.95^{* *}$ \\
\hline \multirow{2}{*}{ Length $(\mathrm{cm})$} & Yes & $8.55 \mathrm{a}$ & $9.32 \mathrm{~b}$ & $9.51 b$ & $9.27 \mathrm{a}$ & $8.56 \mathrm{a}$ & $\mathrm{y}=8.571 * *+0.0319 \mathrm{x} * *-0.00026 \mathrm{x}^{2 * *}$ & $0.99 * *$ \\
\hline & No & $7.42 b$ & $10.62 \mathrm{a}$ & $10.60 \mathrm{a}$ & $9.51 \mathrm{a}$ & $8.75 \mathrm{a}$ & $\mathrm{y}=7.784 * *+0.0908 \mathrm{x}^{* *}-0.00071 \mathrm{x}^{2 * *}$ & $0.82 * *$ \\
\hline \multirow{2}{*}{ Width (cm) } & Yes & $5.15 \mathrm{a}$ & $5.56 \mathrm{~b}$ & $5.79 \mathrm{~b}$ & $5.54 \mathrm{a}$ & $5.16 \mathrm{a}$ & $\mathrm{y}=5.147 * *+0.0195 \mathrm{x}^{* *}-0.00016 \mathrm{x}^{2 * *}$ & $0.98 * *$ \\
\hline & No & $4.40 \mathrm{~b}$ & $5.78 \mathrm{a}$ & $5.92 \mathrm{a}$ & $5.54 \mathrm{a}$ & $5.25 \mathrm{a}$ & $\mathrm{y}=4.528 * *+0.0418 \mathrm{x}^{* *}-0.0003 \mathrm{x}^{2 * *}$ & $0.88 * *$ \\
\hline \multicolumn{9}{|c|}{$2^{\circ}$ Cycle } \\
\hline \multirow{2}{*}{ BW (g) } & Yes & $88.1 \mathrm{a}$ & $90.5 \mathrm{~b}$ & $99.2 \mathrm{~b}$ & $93.0 \mathrm{~b}$ & $79.4 \mathrm{~b}$ & $\mathrm{y}=86.302 * *+0.3983 \mathrm{x}^{* *}-0.0037 \mathrm{x}^{2 * *}$ & $0.85^{* *}$ \\
\hline & No & $80.4 \mathrm{~b}$ & $101.1 \mathrm{a}$ & $106.0 \mathrm{a}$ & $97.6 \mathrm{a}$ & $83.6 \mathrm{a}$ & $\mathrm{y}=81.390 * *+0.7962 \mathrm{x} *-0.0065 \mathrm{x}^{2 * *}$ & $0.98 * *$ \\
\hline \multirow{2}{*}{ NBB } & Yes & $33.9 \mathrm{a}$ & $35.8 \mathrm{~b}$ & $36.5 b$ & $35.2 \mathrm{a}$ & $30.4 \mathrm{a}$ & $\mathrm{y}=33.748 * *+0.1194 \mathrm{x}^{* *}-0.0012 \mathrm{x}^{2 * *}$ & $0.97 * *$ \\
\hline & No & $31.1 \mathrm{~b}$ & 38.6a & $39.9 \mathrm{a}$ & $36.0 \mathrm{a}$ & $30.6 \mathrm{a}$ & $\mathrm{y}=31.516 * *+0.2832 \mathrm{x} * *-0.0024 \mathrm{x}^{2 * *}$ & $0.97 * *$ \\
\hline \multirow{2}{*}{ 10BW (g) } & Yes & $30.8 \mathrm{a}$ & $31.8 \mathrm{~b}$ & $32.5 \mathrm{~b}$ & $33.2 \mathrm{~b}$ & $28.0 \mathrm{~b}$ & $\mathrm{y}=30.271 * *+0.1052 \mathrm{x} * *-0.0098 \mathrm{x}^{2 * *}$ & $0.78 * *$ \\
\hline & No & $28.9 \mathrm{~b}$ & $32.9 \mathrm{a}$ & $34.3 \mathrm{a}$ & $34.7 \mathrm{a}$ & $29.9 \mathrm{a}$ & $\mathrm{y}=28.705^{* *+0}+191 \mathrm{x}^{* *}-0.0014 \mathrm{x}^{2 * *}$ & $0.95^{* *}$ \\
\hline \multirow{2}{*}{ Length $(\mathrm{cm})$} & Yes & $8.33 \mathrm{a}$ & $9.55 b$ & $9.74 b$ & $9.50 \mathrm{a}$ & $8.79 \mathrm{a}$ & $\mathrm{y}=8.393 * *+0.0438 \mathrm{x} * *-0.00034 \mathrm{x}^{2 * *}$ & $0.97 * *$ \\
\hline & No & $7.19 b$ & $10.86 a$ & $10.82 \mathrm{a}$ & $9.74 \mathrm{a}$ & $8.98 \mathrm{a}$ & $\mathrm{y}=7.607 * *+0.1027 \mathrm{x}^{* *}-0.00078 \mathrm{x}^{2 * *}$ & $0.82 * *$ \\
\hline \multirow{2}{*}{ Width (cm) } & Yes & $5.06 \mathrm{a}$ & $5.65 \mathrm{~b}$ & $5.88 \mathrm{~b}$ & $5.63 \mathrm{a}$ & $5.25 \mathrm{a}$ & $\mathrm{y}=5.078 * *+0.0241 \mathrm{x}^{* *}-0.00019 \mathrm{x}^{2 * *}$ & $0.98 * *$ \\
\hline & No & $4.30 \mathrm{~b}$ & $5.87 \mathrm{a}$ & $6.01 \mathrm{a}$ & $5.63 \mathrm{a}$ & $5.34 \mathrm{a}$ & $\mathrm{y}=4.458^{* *}+0.0464 \mathrm{x}^{* *}-0.00033 \mathrm{x}^{2 * *}$ & $0.87 * *$ \\
\hline
\end{tabular}

OrF $=$ organic fertilizer; $\mathrm{BW}=$ bunch weight; $10 \mathrm{BW}=10$-berry weight; $\mathrm{NBB}=$ number of berries per bunch. Means followed by the same letter in the columns ( $\mathrm{N}$ rates within OrF rates) do not differ by the $\mathrm{t}$ test $(p \leq 0,05)$. Data fitted to regression models in the rows (OrF rates within $\mathrm{N}$ rates). $*=$ significant at 0.05 , and $* *$ significant at 0.01 probability by the $\mathrm{F}$ test.

The BW means found in both OrF rates within the $\mathrm{N}$ rates fitted to the quadratic regression model $(p \leq 0.01)$. BW increases with increasing $\mathrm{N}$ rates up to a certain point, regardless of the OrF application. The combined effect of $\mathrm{N}$ and $\mathrm{OrF}$ on $\mathrm{BW}$ was more significant than the effect of $\mathrm{N}$ fertilization without $\mathrm{OrF}$. The highest $\mathrm{BW}$ were $104.3 \mathrm{~g}$ in the first $(60.0$ of $\mathrm{N})$, and $105.7 \mathrm{~g}$ in the second cycle $\left(61.2 \mathrm{~kg} \mathrm{ha}^{-1}\right.$ of $\left.\mathrm{N}\right)$, when combined with OrF; and 95.7 in the first (51.0 of N), and $97.0 \mathrm{~g}$ in the second cycle $\left(53.8 \mathrm{~kg} \mathrm{ha}^{-1}\right.$ of $\left.\mathrm{N}\right)$ with no OrF application (Table 4). The best results can be attributed to the nutrients present in the OrF (Table 3 ), which may have been released more gradually to the soil, better meeting the needs of the plants.

Considering the means of the BW of the two cycles, a gain of $8.2 \mathrm{~g}$ per bunch was achieved with the combination of $\mathrm{N}$ and $\mathrm{OrF}$, representing a significant increase in the production. Brunetto et al. (2009) tested increasing $\mathrm{N}$ rates $(0.15,30.45$, and 
$60 \mathrm{~kg} \mathrm{ha}^{-1}$ ) on Cabernet Sauvignon grapevines and found a positive linear response of $\mathrm{BW}$; they attributed this result to the soil sandy texture with low organic matter content, which generates a low natural availability of nutrients, and to the fertilization, which provided better conditions to the plants.

The number of berries per bunch (NBB) found in the $\mathrm{N}$ rates within the OrF rates showed that $\mathrm{N}$ rates of 30 and $60 \mathrm{~kg} \mathrm{ha}^{-1}$ generated the highest $\mathrm{NBB}$, indicating that these $\mathrm{N}$ rates generated better conditions for the availability of nutrients by the OrF. The OrF presented no effect when applied with no $\mathrm{N}$ fertilization, due to the same reasons described for BW. The NBB means were similar for the N rates of 90 and $120 \mathrm{~kg} \mathrm{ha}^{-1}$, denoting that application of $\mathrm{N}$ rates above the needs of the plant, reduce $\mathrm{NBB}$, regardless of its combination with OrF.

This result can be explained by the imbalance due to excess $\mathrm{N}$ available to plants. The plants had satisfactory water supply through irrigation, and ready availability of nutrients, generating optimal conditions for vegetative development to the detriment of the reproductive, because $\mathrm{N}$ is the element that most affects the vigor of the grapevines in production, affecting productivity factors, and quality and composition of the grape (BRUNETTO et al., 2013; MELO; BRUNETTO; CERETTA, 2016).

The NBB means found in both OrF rates within the $\mathrm{N}$ rates fitted to the quadratic regression model. The maximum NBB was 36.7 and 39.8 at N rates of 59.0 and $59.2 \mathrm{~kg} \mathrm{ha}^{-1}$ combined with OrF, in the first cycle and second cycle, respectively. The highest NBB were 33.8 and 36.7 at $\mathrm{N}$ rates of 49.7 and $49.9 \mathrm{~kg} \mathrm{ha}^{-1}$ with no OrF, in the first cycle and second cycle, respectively (Table 4). Considering the mean NBB of the two cycles, there was a gain of 2.9 berries per bunch with $\mathrm{N}$ fertilization combined with OrF. The best results with application of $\mathrm{N}$ combined with OrF were due to the better nutritional status of the plants, because of the more gradually release of nutrients by the OrF, meeting the needs of the plants (MELO et al., 2012). Therefore, the use of OrF increases in certain way the NBB.

Rocha, Bassoi and Silva (2015) conducted a similar study using Syrah grapevines in three crop cycles and found positive results for the use of OrF in NBB only in the last cycle, however, the $\mathrm{N}$ rates $\left(0,10,20,40\right.$ and $\left.80 \mathrm{~kg} \mathrm{ha}^{-1}\right)$ showed no significant effect on NBB. Brunetto et al. (2013) evaluated Cabernet Sauvignon grapevines with application of $40 \mathrm{~kg} \mathrm{ha}^{-1}$ of $\mathrm{N}$, using urea and organic compost as sources of $\mathrm{N}$, and found no significant difference in $\mathrm{NBB}$, but reported a trend of increase for NBB with the use of the organic compound.

All $\mathrm{N}$ rates within the OrF rates resulted in higher 10-berry weight (10BW), except the $\mathrm{N}$ rate of $0 \mathrm{~kg} \mathrm{ha}^{-1}$, which had no effect with the addition of OrF (Table 4). The 10BW data of both OrF rates within the $\mathrm{N}$ rates fitted to the quadratic regression model, with best results at the $\mathrm{N}$ rates of 63.6 and $68.2 \mathrm{~kg} \mathrm{ha}^{-1}$ combined with OrF, resulting in a $10 \mathrm{BW}$ of $34.3 \mathrm{~g}$ in the first, and $35.2 \mathrm{~g}$ in the second cycle, respectively; whereas the $\mathrm{N}$ rates with no OrF had the best results at the $\mathrm{N}$ rates of 53.7 and $53.6 \mathrm{~kg}$ $\mathrm{ha}^{-1}$, resulting in a $10 \mathrm{BW}$ of 32.6 and $33.1 \mathrm{~g}$, respectively. The means of the 10BW of the two cycles showed that the use of OrF provided a gain of $1.9 \mathrm{~g}$ in the 10BW. Brunetto et al. (2009) also found a quadratic response of berry weight with increasing $\mathrm{N}$ rates $\left(0,15,30,45\right.$, and $\left.60 \mathrm{~kg} \mathrm{ha}^{-1}\right)$ on Cabernet Sauvignon grapevines, and the highest results with $20 \mathrm{~kg} \mathrm{ha}^{-1}$ of $\mathrm{N}$.

The bunch length and width followed the same trend of the previous variables. The $\mathrm{N}$ rates of 30 and $60 \mathrm{~kg} \mathrm{ha}^{-1}$ within the OrF rates showed better results, and the $\mathrm{N}$ rate of $0 \mathrm{~kg} \mathrm{ha}^{-1}$ with OrF had no effect on these variables. The $\mathrm{N}$ rates of 90 and 120 $\mathrm{kg} \mathrm{ha}^{-1}$ resulted in similar bunch length, and width, indicating that the application of $\mathrm{N}$ changes the nutrient release of the OrF.

The bunch length and width in both OrF rates within the $\mathrm{N}$ rates fitted to the quadratic regression model, but with higher results when using OrF (Table 4). The largest bunch length and width were 10.69 and $5.98 \mathrm{~cm}$ for the first, and 10.99 and 6.09 $\mathrm{cm}$ for the second cycle, with $\mathrm{N}$ rates of $63.9,69.7$, 65.8 , and $70.3 \mathrm{~kg} \mathrm{ha}$ combined with OrF, respectively. The highest bunch length and width with no OrF were 9.55 and $5.74 \mathrm{~cm}$ in the first, and 9.80 and $5.84 \mathrm{~cm}$ in the second cycle, with $\mathrm{N}$ rates of $61.3,60.9,64.4$, and $63.4 \mathrm{~kg} \mathrm{ha}^{-1}$, respectively.

The means of the bunch length and width of the two cycles showed an increase of $12 \%$ in bunch length, and $4.2 \%$ in bunch width, when $\mathrm{N}$ rates were combined with OrF. Excessive use of nitrogen fertilizers can have a negative effect on the crop, and $\mathrm{N}$ fertilization to grapevines should be carried out with caution, since it affects the vegetative growth of the plants, as also found by Brunetto et al. (2009; 2013). Increases in $N$ rates with detrimental results was also observed by Bustamante et al. (2011) in grapevine, and by Sete et al. (2015) in peach crops.

Application of high $\mathrm{N}$ rates in vineyards increase mineral $\mathrm{N}$ in the soil, which can stimulate vegetative growth of the plant shoots, reducing the solar radiation inside the canopy of the plants, favoring the appearance of fungal diseases in leaves and bunches, and reducing the number of fertilized flowers, affecting the NBB and the crop yield (BRUNETTO et al., 2007; 2009).

The number of bunches per plant (NBP) in the $\mathrm{N}$ rates within the OrF rates had similar trend to the bunch length and width. The OrF rates within the $\mathrm{N}$ rates showed NBP of 121.6 in the first, and 127.4 in the second cycle, with $\mathrm{N}$ rates of 63.8 , and $65.1 \mathrm{~kg}$ $\mathrm{ha}^{-1}$ with OrF, respectively. In the absence of OrF, the highest NBP was 98.8 and 105.2 with the $\mathrm{N}$ rates of 72.5 and $74.4 \mathrm{~kg} \mathrm{ha}^{-1}$ in the first and second 
cycles, respectively (Table 5). Considering the mean rates of $\mathrm{N}$ in the two cycles, when only $\mathrm{N}$ was used, $9.0 \mathrm{~kg} \mathrm{ha}^{-1}$ of $\mathrm{N}$ were needed to reach the point of maximum agronomic efficiency. Although a larger amount of $\mathrm{N}$ was required, there was a reduction of 22.5 bunches per plant, representing a difference approximately $22 \%$ from the NBP found with $\mathrm{N}$ rates combined with OrF.

Table 5. Number of bunches per plant (NBP), production per plant (PPP), and grape yield (GY) of grapevines of the IsabelPrecoce cultivar as a function of nitrogen fertilization, with and without the use of organic fertilizer, in two production cycles.

\begin{tabular}{|c|c|c|c|c|c|c|c|c|}
\hline \multirow{2}{*}{$\mathrm{PC}$} & \multirow{2}{*}{ OrF } & \multicolumn{5}{|c|}{ Nitrogen rates $\left(\mathrm{kg} \mathrm{ha}^{-1}\right)$} & \multirow[t]{2}{*}{ Equation } & \multirow[t]{2}{*}{$\mathrm{R}^{2}$} \\
\hline & & 0 & 30 & 60 & 90 & 120 & & \\
\hline \multicolumn{9}{|c|}{$1^{\circ}$ Ciclo } \\
\hline \multirow{2}{*}{ NBP } & Yes & $68.2 \mathrm{a}$ & $83.3 \mathrm{~b}$ & $104.0 \mathrm{~b}$ & $92.8 \mathrm{a}$ & $86.2 \mathrm{a}$ & $\mathrm{y}=66.971 * *+0.8802 \mathrm{x}^{* *}-0.00607 \mathrm{x}^{2 * *}$ & $0.88 * *$ \\
\hline & No & $58.2 \mathrm{~b}$ & $115.2 \mathrm{a}$ & $125.0 \mathrm{a}$ & $96.5 \mathrm{a}$ & $82.8 \mathrm{a}$ & $\mathrm{y}=63.733 * *+1.8133 \mathrm{x}^{* *}-0.0142 \mathrm{x}^{2 * *}$ & $0.85 * *$ \\
\hline \multirow{2}{*}{ PPP } & Yes & $5.92 \mathrm{a}$ & $6.75 b$ & $11.14 b$ & $7.96 \mathrm{~b}$ & $6.57 \mathrm{a}$ & $\mathrm{y}=5.553 * *+0.0985 \mathrm{x} * *-0.00076 \mathrm{x}^{2 * *}$ & $0.74 * *$ \\
\hline & No & $4.69 b$ & $11.13 \mathrm{a}$ & $12.58 \mathrm{a}$ & $8.82 \mathrm{a}$ & $6.42 \mathrm{a}$ & $\mathrm{y}=5.242 * *+0.220 \mathrm{x}^{* *}-0.0018 \mathrm{x}^{2} * *$ & $0.88 * *$ \\
\hline \multirow{2}{*}{ GY } & Yes & $9.87 \mathrm{a}$ & $11.25 \mathrm{~b}$ & $16.28 b$ & $13.27 \mathrm{~b}$ & $10.70 \mathrm{a}$ & $\mathrm{y}=9.258^{* *+0}+1642 \mathrm{x}^{* *}-0.0012 \mathrm{x}^{2 * *}$ & $0.74 * *$ \\
\hline & No & $7.82 b$ & $18.57 \mathrm{a}$ & $20.97 \mathrm{a}$ & $14.71 \mathrm{a}$ & $10.96 \mathrm{a}$ & $\mathrm{y}=8.739 * *+0.366 \mathrm{x}^{* *}-0.0029 \mathrm{x}^{2} * *$ & $0.88 * *$ \\
\hline \multicolumn{9}{|c|}{$2^{\circ}$ Ciclo } \\
\hline \multirow{2}{*}{ NBP } & Yes & $65.2 \mathrm{a}$ & $88.2 \mathrm{~b}$ & $109.5 b$ & $97.8 \mathrm{a}$ & $87.8 \mathrm{a}$ & 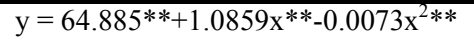 & $0.93 * *$ \\
\hline & No & $55.2 \mathrm{~b}$ & $120.2 \mathrm{a}$ & $130.0 \mathrm{a}$ & $101.5 \mathrm{a}$ & $91.2 \mathrm{a}$ & $\mathrm{y}=61.647 * *+2.019 \mathrm{x} * *-0.0155 \mathrm{x}^{2 * *}$ & $0.85 * *$ \\
\hline \multirow{2}{*}{ PPP } & Yes & $5.68 \mathrm{a}$ & $8.10 \mathrm{~b}$ & $10.99 b$ & $9.21 \mathrm{~b}$ & $7.35 \mathrm{a}$ & $\mathrm{y}=5.490 * *+0.1407 \mathrm{x} * *-0.001 \mathrm{x}^{2 * *}$ & $0.91 * *$ \\
\hline & No & $4.39 \mathrm{~b}$ & $12.30 \mathrm{a}$ & $13.92 \mathrm{a}$ & $10.03 \mathrm{a}$ & $7.48 \mathrm{a}$ & $\mathrm{y}=5.064 * *+0.2651 \mathrm{x}^{* *}-0.0021 \mathrm{x}^{2 * *}$ & $0.89^{* *}$ \\
\hline \multirow{2}{*}{ GY } & Yes & $9.48 \mathrm{a}$ & $13.50 \mathrm{~b}$ & $18.32 \mathrm{~b}$ & $15.35 \mathrm{~b}$ & $12.25 \mathrm{a}$ & $\mathrm{y}=9.152 * *+0.2346 \mathrm{x} * *-0.0017 \mathrm{x}^{2 * *}$ & $0.91 * *$ \\
\hline & No & $7.32 b$ & $20.50 \mathrm{a}$ & $23.21 \mathrm{a}$ & $16.71 \mathrm{a}$ & $12.41 \mathrm{a}$ & $\mathrm{y}=8.441 * *+0.4419 \mathrm{x} * *-0.0035 \mathrm{x}^{2 * *}$ & $0.89^{* *}$ \\
\hline
\end{tabular}

$\mathrm{PC}=$ production component; $\mathrm{PPP}=\mathrm{kg}$ planta $^{-1} ; \mathrm{GY}=\mathrm{Mg} \mathrm{ha}^{-1}$. Means followed by the same letter in the columns $(\mathrm{N}$ rates within OrF rates) do not differ by the $t$ test $(p \leq 0,05)$. Data fitted to regression models in the rows (OrF rates within $\mathrm{N}$ rates). $*$ = significant at 0.05 , and $* *$ significant at 0.01 probability by the $\mathrm{F}$ test.

These results can be explained by the soil improvement due to the use of OrF regarding macro and micronutrients (Table 3), and physical, chemical, and microbial characteristics (MALAVOLTA, 2006). Rocha, Bassoi and Silva (2015) evaluated Syrah grapevines with increasing $\mathrm{N}$ rates $(0,10,20$, 40 and $80 \mathrm{~kg} \mathrm{ha}^{-1}$ ) applied singly or combined with $\mathrm{OrF}$ and found no significant difference for NBP, because of internal nutrient reserves in perennial organs of the plants may have met their demands. Thus, the amount of $\mathrm{N}$ available in the soil and the internal nitrogen reserves may have been sufficient for the plants, contrasting with the results found in the present work with Isabel-Precoce grapevines under local conditions.

Lorensini et al. (2015) evaluated Cabernet Sauvignon grapevines with annual application of $\mathrm{N}$ rates $\left(0,10,15,20,40,80\right.$, and $\left.120 \mathrm{~kg} \mathrm{ha}^{-1}\right)$ and found a quadratic effect for NBP, with the best results obtained with the $\mathrm{N}$ rate of $20 \mathrm{~kg} \mathrm{ha}^{-1}$. Casali et al. (2015) evaluated the productivity of Niagara
Rosada grapevines with increasing bovine manure rates $\left(0,9,18,36\right.$, and $72 \mathrm{~L} \mathrm{plant}^{-1}$ year $\left.{ }^{-1}\right)$ and also found a quadratic effect for NBP, and the best results were obtained with the use of $9 \mathrm{~L}$ manure plant ${ }^{-1}$; higher $\mathrm{N}$ rates reduced the NBP, and the authors attributed this result to the excess of $\mathrm{N}$ provided by the organic fertilizer.

The production per plant (PPP) found in the $\mathrm{N}$ rates within OrF rates showed better results with $\mathrm{N}$ rates of 30,60 , and $90 \mathrm{~kg} \mathrm{ha}^{-1}$; in these rates the OrF had better conditions to make nutrients available. The OrF application had no effect with the $\mathrm{N}$ rate of $0 \mathrm{~kg} \mathrm{ha}^{-1}$. The $\mathrm{N}$ rate of $120 \mathrm{~kg} \mathrm{ha}^{-1}$ resulted in similar PPP in both OrF rates (Table 5). Applications of $\mathrm{N}$ rates above the needs of the plant decreased PPP, regardless the application of OrF.

However, the results of PPP found in both OrF rates within the $\mathrm{N}$ rates, based on the regression equations, the highest PPP is found with $\mathrm{N}$ rates of 61.1 and $63.2 \mathrm{~kg} \mathrm{ha}^{-1}$ are applied with the use of OrF. These rates result in $11.98 \mathrm{Kg}$ for the first, and 
$13.43 \mathrm{~kg}$ for the second cycle. The PPP were $8.74 \mathrm{~kg}$ and $10.4 \mathrm{~kg}$ without the use of OrF, with $\mathrm{N}$ rates of 64.8 and $70.3 \mathrm{~kg} \mathrm{ha}^{-1}$, in the first and second cycles, respectively (Table 5). According to the means of the PPP of the two cycles, $5.4 \mathrm{~kg} \mathrm{ha}^{-1}$ of $\mathrm{N}$ is required to reach maximum production using only $\mathrm{N}$ (urea). When $\mathrm{N}$ rates were combined with OrF, a smaller amount of the mineral fertilizer was required, and the production was $3.1 \mathrm{~kg}$ higher per plant, representing a difference of approximately $32.7 \%$. Brunetto et al. (2009) evaluated Cabernet Sauvignon grapevines subjected to $\mathrm{N}$ fertilization and found the highest yields with applications of 15 to $30 \mathrm{~kg} \mathrm{ha}^{-1} \mathrm{~N}$, thus, under the conditions of the study, the highest $\mathrm{N}$ rates provide no increase in plant production.

Lorensini et al. (2015) evaluated the application of increasing $\mathrm{N}$ rates in Cabernet Sauvignon grapevines in three crop seasons and found a quadratic response for PPP, with the best results found in the $\mathrm{N}$ rate of $20 \mathrm{~kg} \mathrm{ha}^{-1}$. They attribute this result to the higher NBP and bunch weight, as found in the present work for IsabelPrecoce grapevines. The positive effect of these parameters can be attributed to the $\mathrm{N}$ uptake, since the soil of the study area had low organic matter contents $\left(<10 \quad \mathrm{~g} \mathrm{~kg}^{-1}\right)$ and, consequently, low nitrogen availability. Therefore, annual application of $\mathrm{N}$ (urea or organic source) to the soil is necessary to obtain better production results (LORENSINI et al., 2012; (NASCIMBENE; MARINI; PAOLETT, 2012).

The yields (GY) of the grapevines found in the $\mathrm{N}$ rates within the OrF rates showed the same trend of the PPP. However, the results of the GY in both OrF rates within the $\mathrm{N}$ rates fitted to the quadratic model, regardless of the OrF application (Table 5), with the best results obtained with the $\mathrm{N}$ rate of $63.1 \mathrm{~kg} \mathrm{ha}^{-1}$ with OrF, resulting in a GY of 20.3 $\mathrm{Mg} \mathrm{ha}^{-1}$ for the first, and $22.4 \mathrm{Mg} \mathrm{ha}^{-1}$ for the second cycle. The best results with no OrF application were $14.9 \mathrm{Mg} \mathrm{ha}^{-1}$ and $17.2 \mathrm{Mg} \mathrm{ha}^{-1}$, with the $\mathrm{N}$ rates of 68.4 and $69.0 \mathrm{~kg} \mathrm{ha}^{-1}$ for the first and second cycles, respectively. Therefore, high $\mathrm{N}$ rates is necessary to achieve better GY when no OrF is applied, and the GY is approximately $33 \%$ lower when compared to the $\mathrm{N}$ application combined with OrF.

Rocha, Bassoi and Silva (2015) evaluated three crop cycles of Syrah grapevines in the Brazilian semiarid region with application of OrF (goat manure) combined with $\mathrm{N}$ rates $(0,10,20,40$, and $80 \mathrm{~kg} \mathrm{ha}^{-1}$ ) and found effect of the use of OrF in GY only in the last cycle. This result denotes the benefits of OrF on soil characteristics that is commonly found in grapevines cultivated in the region. Although the process of mineralization of soil organic matter (SOM) occurs with greater intensity in tropical conditions, the continuous application of OrF (manures) can provide a better balance between the transformation processes of
SOM, contributing to the improvement of soil fertility. Mugnai et al. (2012) also showed positive effects of organic matter on characteristics of soils under Chardonnay grapevine crops subjected to organic fertilization.

Several studies on grapevines using increasing $\mathrm{N}$ rates (BRUNETTO et al., 2009; LORENSINI et al., 2015), urea and organic fertilizer (BRUNETTO et al., 2013), and increasing rates of OrF (CASALI et al., 2015) found that excessive rates of $\mathrm{N}$ or organic materials hinder their production components. It was also observed in the present study; high $\mathrm{N}$ rates from urea $(90$ and $120 \mathrm{~kg}$ $\mathrm{ha}^{-1}$ ) or from OrF (approximately $131.0 \mathrm{~kg} \mathrm{ha}^{-1}$ ) (Table 3) generated excess $\mathrm{N}$ in the soil, causing significant decreases in the production of the grapevines. The use of high rates of $\mathrm{N}$ provide no benefits and hinders productivity of the plants, causing economic losses, and has environmental consequences, such as the contamination of the water table with nitrate due to the leaching process (LORENSINI et al. al., 2012).

Thus, high $\mathrm{N}$ rates are not appropriate for the study conditions because they reduce the yield of Isabel-Precoce grapevines. This is also attributed to a disordered increase in leaf area of the plants to the detriment of production components DUCHÊNE; SCHNEIDER; GAUDILLÈRE, 2001). Plants treated with the highest $\mathrm{N}$ rates had higher leaf canopy (data not shown). Piva et al. (2013) evaluated the effect of plant ash rates $\left(0,750,1,500\right.$ and 2,250 $\left.\mathrm{g} \mathrm{plant}^{-1}\right)$, and bovine manure rates $\left(0,5\right.$, and $\left.10 \mathrm{~kg} \mathrm{plant}^{-1}\right)$ in Isabel grapevines and found a positive linear effect on leaf area with increasing manure and ash rates. Nascimento et al. (2014) also evaluated Isabel grapevines with biofertilizer rates and found increases in leaf area depending on the biofertilizer used. The authors of these two studies attributed the leaf area increase to the high $\mathrm{N}$ rates contained in the inputs applied to the soil.

Different results of the effect of $\mathrm{N}$ on productive components of grapevines are found in scientific literature; however, it is consensus that excess $\mathrm{N}$ has negative effect on them. More detailed information on these effects, considering the soil and climate characteristics of the semiarid region, is necessary, especially regarding the use of alternative sources of fertilizers. These fertilizers are usually from local accessible sources. The use of alternative sources of nutrients should be considered because of the increasing prices of mineral fertilizers in the national market.

The current large-scale production of large part of the Brazilian agriculture makes it almost impossible to adopt only organic fertilizers because of the logistic involved. However, this is a viable alternative for small and medium farmers, mainly fruit producers, since the use of OrF result in better productions. The good results found in the $\mathrm{N}$ rate of $30 \mathrm{~kg} \mathrm{ha}^{-1}$ combined with OrF application denoted 
that strategies using less mineral fertilization can be adopted, by adding organic inputs (animal manures) as a complementary fertilization.

\section{CONCLUSIONS}

The nitrogen rate of $60 \mathrm{~kg} \mathrm{ha}^{-1}$ combined with the application of organic fertilizer (bovine manure) provided the best results for the production components analyzed. Increasing $\mathrm{N}$ rates from 60 to $120 \mathrm{~kg} \mathrm{ha}^{-1}$ hinders productive components of grapevines of the Isabel-Precoce cultivar, regardless of the combination with organic sources.

\section{REFERENCES}

BASSOI, L. H. et al. Preliminary results of a longterm experiment about RDI and PRD irrigation strategies in wine grape in São Francisco Valley, Brazil. Acta Horticulturae, v. 754, n. 35, p. 275282, 2007.

BRUNETTO, G. et al. Aplicação de nitrogênio em videiras na Campanha Gaúcha: produtividade e características químicas do mosto da uva. Ciência Rural, v. 37, n. 2, p. 389-393, 2007.

BRUNETTO, G. et al. Application of nitrogen sources on grapevines and effect on yield and must composition. Revista Brasileira de Fruticultura, v. 35, n. 4, p. 1042-1051, 2013.

BRUNETTO, G. et al. Produção e composição química da uva de videiras Cabernet Sauvignon submetidas à adubação nitrogenada. Ciência Rural, v. 39, n. 7, p. 2035-2041, 2009.

BUSTAMANTE, M. A. et al. Application of winery and distillery waste composts to a Jumilla (SE Spain) vineyard: effects on the characteristics of a calcareous sandy-loam soil. Agriculture Ecosystems Environment, v. 140, n. 1, p. 80-87. 2011.

CARVAlHO, C. de et al. Anuário Brasileiro da Fruticultura 2017. Santa Cruz do Sul, RS: GAZETA, 2017. 88 p.

CASALI, Â. V. et al. Estado nutricional, produção e composição das uvas de 'Niágara Rosada' submetidas à aplicação de composto orgânico. Revista de Ciências Agrárias. v. 58, n. 3, p. 257 262, 2015.

CASTOLDI, G. et al. Sistemas de produção e sua influência na cultura do milho safrinha em plantio direto. Scientia Agraria Paranaensis, v. 10, n. 1, p.
47-57, 2011.

CUNHA, T. J. F. et al. A pesquisa em ciência do solo no Semiárido brasileiro. In: ALBUQUERQUE, A. C. S.; SILVA, A. G. da. (Eds.). Agricultura tropical: quatro décadas de inovações tecnológicas, institucionais e políticas. Brasília: Embrapa Informação Tecnológica, 2008. v. 2, cap. 5, p. 453-491.

CUNHA, T. J. F. et al. Principais solos do semiárido tropical brasileiro: caracterização, potencialidades, limitações, fertilidade e manejo. In: SA, I. B.; SILVA, P. C. G. da. (Eds.). Semiárido brasileiro: pesquisa, desenvolvimento e inovação. Petrolina: Embrapa Semiárido, 2010. v. 3, cap. 4, p. 50-87.

DUCHÊNE, E.; SCHNEIDER, C.; GAUDILLÈRE, J. P. Effects of nitrogen nutrition timing on fruit set of grapevine cv. Grenache. Vitis, v. 40, n. 1, p. 4546, 2001.

ECKHARDT, D. P. et al. Mineralization and efficiency index of nitrogen in cattle manure fertilizers on the soil. Ciência Rural, v. 46, n. 3, p. 472-477, 2016

EMPRESA BRASILEIRA DE PESQUISA AGROPECUÁRIA - EMBRAPA. Manual de métodos de análise de solo. 3.ed. Rio de Janeiro, RJ: EMBRAPA/CNPS, 2011. 230 p.

FREITAS, M. S. C.; ARAÚJO, C. A. S.; SILVA, D. J. Decomposição e liberação de nutrientes de estercos em função da profundidade e do tempo de incorporação. Revista Semiárido De Visu, v. 2, n. 1, p. 150-161, 2012.

INSTITUTO AGRONÔMICO DE PERNAMBUCO - IPA. Recomendações de adubação para o Estado de Pernambuco. 3. ed. Recife, PE: IPA, 2008. 64 p.

LORENSINI, F. et al. Lixiviação e volatilização de nitrogênio em um Argissolo cultivado com videira submetida a adubação nitrogenada. Ciência Rural, v. 42, n. 7, p. 1173-1179, 2012.

LORENSINI, F. et al. Disponibilidade de nitrogênio de fontes minerais e orgânicas aplicadas em um Argissolo cultivado com videira. Revista Ceres, v. 61, n. 2 , p. $241-247,2014$

LORENSINI, F. et al. Nitrogen fertilization of Cabernet Sauvignon grapevines: yield, total nitrogen content in the leaves and must composition. Acta Scientinarum Agronomy, v. 37, n. 3, p. 321-329, 2015.

LOURENZI, C. R. et al. Atributos químicos de Latossolo após sucessivas aplicações de composto 
orgânico de dejeto líquido de suínos. Pesquisa Agropecuária Brasileira. v. 51, n. 3, p. 233-242, 2016.

MALAVOLTA, E. Manual de nutrição mineral de plantas. 2. ed. São Paulo, SP: Agronômica Ceres, 2006. $638 \mathrm{p}$.

MELO, G. W. B. et al. Resposta das videiras a diferentes modos de distribuição de composto orgânico no solo. Revista Brasileira de Fruticultura, v. 34, n. 2, p. 493-503, 2012.

MELO, G. W. B.; BRUNETTO, J. Z. G.; CERETTA, C. A. Calagem, adubação e contaminação em solos cultivados com videiras. 1 . ed. Bento Gonçalves: Embrapa Uva e Vinho, 2016. 138 p. (Documentos, 100).

MENEZES, R. S. C.; SALCEDO, I. H. Mineralização de $\mathrm{N}$ após incorporação de adubos orgânicos em um Neossolo Regolítico cultivado com milho. Revista Brasileira de Engenharia Agrícola e Ambiental, v. 11, n. 4, p. 361-367, 2007.

MUGNAI, S. et al. Influence of long-term application of green waste compost on soil characteristics and growth, yield and quality of grape (Vitis vinifera L.). Compost Science \& Utilization, v. 20, n. 1, p. 29-33. 2012.

NASCIMBENE, J.; MARINI, L.; PAOLETT, M. G. Organic farming benefits local plant diversity in vineyard farms located in intensive agricultural landscapes. Environmental Management, v. 49, n. 1, p. 1054-1060, 2012.

NASCIMENTO, O. S. et al. Comportamento da área foliar da videira 'Isabel' submetida a diferentes tipos e doses de biofertilizantes. Revista Verde, v. 9, n. 2, p. 52-58, 2014.

PIVA, R. P. et al. Adubação em vinhedo orgânico da cv. 'Isabel' utilizando cinzas vegetais e esterco bovino. Revista Brasileira de Fruticultura, v. 35, n. 2, p. 608-615, 2013.

$\mathrm{R}$ Core Team. R: A language and environment for statistical computing. R Foundation for Statistical Computing, Vienna, Austria. 2015. Disponível em: $<$ https://www.R-project.org/>. Acesso em: 03 set. 2015.

RÊGO, L. G. S. et al. Pedogenesis and soil classification of an experimental farm in Mossoró, State of Rio Grande do Norte, Brazil. Revista Caatinga, v. 29, n. 4, p. 1036-1042, 2016.

ROCHA, M. G.; BASSOI, L. H.; SILVA, D. J.
Atributos do solo, produção da videira'Syrah' Irrigada e composição do mosto em função da adubação orgânica e nitrogenada. Revista Brasileira de Fruticultura, v. 37, n. 1, p. 220-229, 2015.

SETE, P. B. et al. Perdas de nitrogênio do solo e resposta do pessegueiro à adição de composto orgânico. Ciência Rural, v. 45, n. 4, p. 651-657, 2015 .

TEDESCO, M. J. et al. Análise de solo, plantas e outros materiais. 1. ed. Porto Alegre, RS: UFRGS, 1995. $174 \mathrm{p}$. 